\title{
Hyvä toimintatapa eläinten lopetuksessa
}

\author{
Maria Ylä-Ajos ${ }^{1)}$ ja Satu Raussi ${ }^{1,2)}$ \\ ${ }^{1)}$ Eläinten hyvinvoinnin tutkimuskeskus, 00014 HELSINGIN YLIOPISTO, etunimi.sukunimi@ helsinki.fi \\ ${ }^{2)}$ Eläinten hyvinvointikeskus EHK, O0014 HELSINGIN YLIOPISTO
}

\section{Tiivistelmä}

Neuvoston asetus (EY N:o 1099/2009) eläinten suojelusta lopetuksen yhteydessä tulee sovellettavaksi vuoden 2013 alusta. Tämän niin kutsutun lopetusasetuksen määräyksillä pyritään edistämään lopetuksen ja siihen liittyvien toimien suorittamista siten, että eläimiä varjellaan vältettävissä olevalta kivulta, tuskalta ja kärsimykseltä.

Lopetusasetus muun muassa märittelee sallitut lopetusmenetelmät, niiden keskeiset parametrit ja velvoittaa alan toimijat suunnittelemaan eläinten lopetuksen ja siihen liittyvät toimet etukäteen. Etukäteissuunnittelu on todennettava laatimalla toimintaohjeisto. Toimintaohjeiston laatimisessa apuna voi käyttää hyvän toimintatavan oppaita, joita parhaillaan työstetään maa- ja metsätalousministeriön rahoittamissa hankkeissa Helsingin yliopiston eläinlääketieteellisessä tiedekunnassa Eläinten hyvinvointikeskuksessa.

Vuonna 2011 valmistui 'Siipikarjan konttilopetus Suomessa' hankkeessa hyvän toimintatavan opas siipikarjan tiloilla tapahtuvaan kaasulopetukseen. Hankkeen käytännön osuudessa tutustuttiin Suomessa tällä hetkellä käytössä oleviin tapoihin lopettaa munintansa päättäneet kanat ja etsittiin hyviä lopetuskäytäntöjä edelleen jaettaviksi. Hyvä toimintatapa siipikarjan lopetuksessa -oppaassa käydään läpi siipikarjan lopetusta säätelevää lainsäädäntöä, elävien eläinten käsittelyä, käytännön lopetustapahtumaa ja annetaan neuvoja toimintaohjeiston laatimiseen. Opas painottuu erityisesti hiilidioksidilla tapahtuvaan munintansa päättäneiden kanojen lopettamiseen.

Vuoden 2012 alussa alkaneessa 'Hyvä toimintatapa teurastuksessa' hankkeessa tullaan laatimaan erillisiä hyvän toimintatavan oppaita sovellettaviksi sian-, naudan- ja siipikarjan teurastukseen. Hankkeessa selvitetään millaista hyvinvointitietoa teurastamot ja valvovat eläinlääkärit oman työnsä tueksi tarvitsevat. Hyvän toimintatavan oppaat kirjoitetaan tunnistettujen tiedontarpeiden sekä lopetusasetuksen vaatimusten perusteella. Oppaissa keskitytään eläinten käsittelyyn ennen teurastusta, käytettävissä oleviin tainnutusmenetelmiin, menetelmien onnistuneen käytön edellytyksiin, tainnutuksen onnistumisen seurantaan ja eläimen kuoleman varmistamiseen.

Asiasanat: Hyvä toimintatapa, lopetus, teurastus, sika, nauta, siipikarja 


\section{Tausta}

Neuvoston asetus (EY N:o 1099/2009) eläinten suojelusta lopetuksen yhteydessä (lopetusasetus) määrittelee sallitut lopetusmenetelmät ja pyrkii edistämään lopetuksen ja siihen liittyvien toimien suorittamista niin, että eläimiä varjellaan vältettävissä olevalta kivulta, tuskalta ja kärsimykseltä lopetuksen ja siihen liittyvien toimien aikana. Lopetusasetusta sovelletaan vuoden 2013 alusta ja se painottaa etukäteissuunnittelun ja henkilöstön hyvän koulutuksen sekä ammattitaidon merkitystä eläinten käsittelyolosuhteita parantavana tekijänä. Tiettyjä eläviin eläimiin kohdistuvia toimia suorittavalla henkilöstöllä on jatkossa oltava todistus kelpoisuudestaan kyseisiin tehtäviin.

Lopetusasetus velvoittaa alan toimijat suunnittelemaan eläinten lopetuksen ja siihen liittyvät toimet kunkin käytössä olevan lopetusmenetelmän osalta etukäteen laatimalla itselleen riskeihin perustuvan toimintaohjeiston. Toimintaohjeisto on etukäteen tehty kuvaus lopetusmenetelmän asianmukaisesta käytöstä ja asianmukaisen eläinten lopetuksen varmistamiseksi tehdyistä toimenpiteistä. Siinä on esitettävä selkeät tavoitteet, vastuuhenkilöt, toimintatavat ja mitattavissa olevat kriteerit sekä kuvailtava seuranta- ja kirjausmenettelyt. Lopetustapahtuman asianmukainen suoritus tulee todentaa lopetusasetuksen mukaisilla lopetusmenetelmäkohtaisilla keskeisillä parametreilla, joita valvomalla pyritään varmistamaan lopetustapahtuman onnistuminen asianmukaisesti. Esimerkiksi kaasuilla tapahtuvan lopetuksen kohdalla menetelmän keskeisiä parametreja ovat a) lopetukseen käytettävän kaasun pitoisuus (hiilidioksidi, $\mathrm{CO}_{2}$ ) tai inerttejä kaasuja käytettäessä kammion happipitoisuus, b) altistusaika sekä kaasun c) laatu ja d) lämpötila.

Toimintaohjeisto on pyynnöstä annettava toimivaltaiselle viranomaiselle nähtäväksi. Selkeä ja huolellisesti juuri omassa käytössä olevien lopetusmenetelmien käyttöä varten tehty toimintasuunnitelma myös nopeuttaa ja helpottaa lopetustyön suoritusta ja auttaa uusien työntekijöiden perehdytyksessä menetelmän käyttöön.

Lopetusasetuksen mukaan alan toimijajärjestöjen laatimat hyvän toimintatavan oppaat ovat toimijoiden kannalta arvokkaita välineitä, jotka helpottavat tiettyjen asetuksessa säädettyjen vaatimusten noudattamista, kuten esimerkiksi toimintaohjeiston kehittämistä ja soveltamista. Koska tällaisia hyvän toimintatavan oppaita ei Suomessa juurikaan vielä ole, työstetään niitä parhaillaan Eläinten hyvinvointikeskuksessa (EHK).

\section{Hyvä toimintatapa siipikarjan lopetuksessa}

Siipikarjaa voidaan joutua lopettamaan tiloilla tuotantokauden aikana tai sen päätteeksi suuriakin määriä. Eläinmäärällisesti suurin teurastamojen ulkopuolella lopetettava siipikarjaryhmä on munintansa päättäneet kanat. Kanat lopetetaan Suomessa pääasiassa altistamalla ne hiilidioksidikaasulle joko kanalassa tai kanalan läheisyydessä. Lopetusasetuksen mukaisesti siipikarjan lopetuksia tekevien toimijoiden on 1.1.2013 alkaen suoritettava omavalvontaa ja laadittava itselleen toimintaohjeisto. Velvoite ei kuitenkaan koske hätälopetuksia, kuten sairaiden tai vahingoittuneiden yksilöiden lopetusta.

Siipikarjan konttilopetus Suomessa -hankkeessa kirjoitettiin siipikarjan tiloilla tapahtuvaa lopetusta käsittelevä hyvän toimintatavan opas, jota voi hyödyntää toimintaohjeiston laatimisessa.

\section{Hankkeen käytännön toiminta}

Siipikarjan konttilopetus Suomessa -hankkeessa tutustuttiin munintansa päätäneiden kanojen lopetuksen tämänhetkisiin käytäntöihin vierailemalla seitsemällä tilalla, joilla kanojen lopetus oli ajankohtainen. Nykyisen, 31.12.2012 asti sovellettavan lainsäädännön (MMMp 5/EEO/2000) mukaisesti kanat voi lopettaa siirtämällä ne vähintään 70 tilavuus- $\% \mathrm{CO}_{2}$ sisältävään kammioon ja pitämällä siellä kunnes ne ovat kuolleet. Tähän pyritään käyttämällä pääasiassa kahdentyppisiä lopetuskontteja. Hankkeessa seuratut lopetuskontit olivat tyypiltään 1) kanalan ulkopuolelle sijoitettuja suuria kontteja, joihin kanat jouduttiin siirtämään kanalasta tai 2) pieniä, kanalan sisällä liikuteltavia kontteja, joihin kanat nostettiin sisällä kanalassa. Käyntien tarkoituksena oli etsiä hyviä lopetuskäytäntöjä jaettavaksi hyvän toimintatavan oppaassa.

Tilakäynneillä rekisteröitiin koko lopetustapahtuma kanojen keräilystä erityyppisistä kanaloista niiden kuolemaan saakka. Lopetuksen onnistumista arvioitiin seuraamalla konttien $\mathrm{CO}_{2}$-pitoisuutta, lämpötilaa, kosteutta ja eläinten taintumisen nopeutta. Lopetuskonttien $\mathrm{CO}_{2}$-pitoisuutta rekisteröitiin koko tapahtuman ajan Envic Oy:n z199907 hiilidioksidiloggerilla (Envic, Turku, Suomi), joka oli varustettu Sensorexin (Sensorex, Naantali, Suomi) happi-, lämpötila- ja kosteusantureilla. Kanojen altistusta $\mathrm{CO}_{2}$ :lle kuvattiin (Samsung SMX-F40BP, Samsung Electronics co, China) kolmessa kontis- 
sa. Videoilta seurattiin kanojen taintumista ja määritettiin taintumiseen kuluva aika. Eläimen katsottiin olevan tajuton, kun se ei pystynyt enää ylläpitämään seisoma tai istuma asentoaan, eikä kontrolloimaan päänsä liikkeitä (Gerritzen ym., 2004).

Lähes kaikissa lopetuskonteissa $\mathrm{CO}_{2}$-pitoisuus jäi pääosan lopetustapahtumasta alhaisemmaksi kuin $70 \%$. Lopetusasetus tuo mukanaan lievennyksiä vaadittuihin lopetuksessa käytettäviin $\mathrm{CO}_{2^{-}}$ pitoisuuksiin ja se sallii mm. altistuksen asteittain kohoavalle $\mathrm{CO}_{2}$-pitoisuudelle. Siten suurin osa seuratuista konttilopetuksista olisi täyttänyt sovellettavaksi tulevan lopetusasetuksen vaatimukset $\mathrm{CO}_{2^{-}}$ altistuksen osalta vähintään kohtuullisesti. Suurin osa toimijoista pyrki varmistamaan kanojen kuoleman lopetuskontissa nostamalla kontin $\mathrm{CO}_{2}$-pitoisuuden tapahtuman lopuksi noin $80 \%$ :iin ja ylläpitämällä tätä tasoa muutamia minuutteja ennen kontin tyhjennystä.

Kanat taintuivat keskimäärin 17 sekunnissa kontin $\mathrm{CO}_{2}$-pitoisuuden ollessa $65 \%$ ja 38 sekunnissa $\mathrm{CO}_{2}$-pitoisuuden ollessa $35 \%$ (taulukko 1). Tässä mitatut taintumisajat vastaavat tarkoin kontrolloiduissa olosuhteissa mitattuja arvoja, joiden mukaan broilerit menettävät asennon hallintakykynsä 29 sekunnissa altistettaessa ne $40 \% \mathrm{CO}_{2}$ sisältävälle kaasuseokselle (Raj, 1997) ja kanat menettävät tajuntansa 21 sekunnin altistuksessa $45 \% \mathrm{CO}_{2}$ sisältävälle kaasuseokselle (Raj ym., 1990). Hiilidioksidin osuuden kasvattaminen yli 45-50 prosentin ei tutkimusten mukaan juurikaan lyhennä taintumisaikaa (Mohan Raj ja Gregory 1990; Webster ja Fletcher, 2001), mutta pidentää kuolemaan johtavaan altistukseen tarvittavaa aikaa. Tässä hankkeessa tehtyjen seurantojen yhteydessä havaittiin, että korkean $\mathrm{CO}_{2}$-pitoisuuden ylläpitäminen on erittäin suositeltavaa varsinkin pienissä jatkuvatäyttöisissä lopetuskonteissa, jotta kaasun pitoisuuden pysyminen jatkuvasti yli $45 \%$ :n tulee varmistettua ja kanat ehtivät taintua ennen seuraavan eläinkerroksen lisäämistä.

Taulukko 1. Kanojen taintuminen erityyppisissä lopetuskonteissa.

\begin{tabular}{lccccccccc}
\hline & \multicolumn{3}{l}{ Pienkontti1 } & \multicolumn{3}{c}{ Suurkontti } & \multicolumn{3}{c}{ Pienkontti2 } \\
& k.a. & \multicolumn{2}{c}{ Vaihteluväli } & k.a. & \multicolumn{2}{c}{ Vaihteluväli } & k.a. & \multicolumn{2}{c}{ Vaihteluväli } \\
\hline Taintumisaika (s) & 18 & 8 & 40 & 38 & 15 & 74 & 20 & 12 & 39 \\
$\mathrm{n}$ & 21 & & & 24 & & & 22 & & \\
$\mathrm{CO}_{2}-\%$ & 60 & 40 & 85 & 35 & 22 & 85 & 65 & 5 & 80 \\
\hline
\end{tabular}

Lopetusasetus määrittelee kaasuilla tapahtuvan lopetuksen keskeisiksi parametreiksi kaasupitoisuuden ja altistusajan lisäksi kaasun laadun ja lopetuskontin lämpötilan. $\mathrm{CO}_{2}$-pitoisuuden mittauksen yhteydessä rekisteröityjen kontin lämpötilan ja ilmankosteuden perusteella alhainen lämpötila tai ilmankosteus ei ollut ongelmallinen parametri lopetuskontteja käytettäessä. Kontin lämpötila sen sijaan saattaa kohota nopeasti yli $30{ }^{\circ} \mathrm{C}$, jopa yli $40{ }^{\circ} \mathrm{C}$, mikäli käytetään asteittaista altistusta $\mathrm{CO}_{2}: 1 l$, eikä kaasua johdeta konttiin nopeasti. Kaasualtistuksissa käytettiin puhdasta pullotettua $\mathrm{CO}_{2}$ :a.

\section{Hyvän toimintatavan opas siipikarjan lopetukseen}

Löydettyjen hyvien käytäntöjen sekä lopetusasetuksen määräysten perusteella kirjoitettiin hyvän toimintatavan opas siipikarjan kaasuilla tapahtuvaan lopetukseen. Oppaassa on käsitelty siipikarjan lopetusta säätelevää lainsäädäntöä, elävien eläinten käsittelyä, eri lopetusmenetelmiä sekä käytännön lopetustapahtumaa, toimintaohjeiston laatimista ja vastuuhenkilöiden koulutustarvetta. Eläinten hyvinvoinnin kannalta etenkin elävien eläinten käsittely, tainnutuksen ja lopetuksen onnistuminen asianmukaisesti sekä onnistumisen varmistaminen ovat tärkeitä tekijöitä. Opas painottuu erityisesti hiilidioksidilla tapahtuvaan munintansa päättäneiden kanojen lopettamiseen, mutta siinä on käsitelty myös muita siipikarjalajeja ja lopetuskaasuja. Opas julkaistaan Eläinten hyvinvointikeskuksen verkkosivuilla (http://elaintenhyvinvointikeskus.edublogs.org/).

\section{Hyvä toimintatapa teurastuksessa}

Lopetusasetus velvoittaa myös teurastamot laatimaan itselleen kaikki laitoksessa teurastettavat eläinlajit ja käytetyt tainnutusmenetelmät kattavan toimintaohjeiston. Tainnutuksen osalta toimintaohjeistossa on: a) otettava huomioon laitteiden valmistajien suositukset; b) määriteltävä saatavilla olevan tieteellisen näytön perusteella kunkin tainnutusmenetelmän osalta, lopetusasetuksessa säädetyt, keskeiset parametrit, joilla voidaan varmistaa menetelmän tehokkuus eläinten tainnuttamisessa; c) määriteltävä toteutettavat toimenpiteet, jos havaitaan, ettei eläin ole asianmukaisesti tainnutettu tai teurastuksen 
yhteydessä eläin osoittaa yhä elonmerkkejä. Tainnutuksen epäonnistuminen voi aiheuttaa eläimelle kärsimystä, joten toimintaohjeistoon on määriteltävä myös asianmukainen ja saatavilla oleva varatainnutusmenetelmä. Lopetusasetuksen mukaan toimintaohjeiston laatimisessa voi käyttää apuna hyvän toimintatavan oppaita.

Vuoden 2012 alussa alkaneen 'Hyvä toimintatapa teurastuksessa' hankkeen tarkoitus on laatia hyvän toimintatavan oppaita sovellettaviksi eri lajien teurastukseen. Hanke aloitetaan selvittämällä millaista hyvinvointitietoa teurastamot ja valvovat eläinlääkärit oman työnsä tueksi tarvitsevat. Nykyisiä tainnutuskäytäntöjä ja tainnutuksen onnistumisen valvontaa seurataan kymmenessä teurastamossa. Tunnistettujen tiedontarpeiden sekä lopetusasetuksen vaatimusten perusteella laaditaan hyvän toimintatavan oppaat sian-, naudan- ja siipikarjan teurastukseen. Oppaissa keskitytään eläinten käsittelyyn ennen teurastusta, käytettävissä oleviin tainnutusmenetelmiin, menetelmien onnistuneen käytön edellytyksiin, tainnutuksen onnistumisen seurantaan ja eläimen kuoleman varmistamiseen. Oppaat tullaan julkaisemaan Eläinten hyvinvointikeskuksen verkkosivuilla (http://elaintenhyvinvointikeskus.edublogs.org/) sitä mukaa, kun ne valmistuvat.

\section{Kirjallisuus}

Gerritzen, M.A., Lambooij, B., Reimert, H., Stegeman, A. \& Spruijt, B. 2004. On-farm euthanasia of broiler chickens: effects of different gas mixtures on behavior and brain activity. Poultry Science, 83(8), 1294-1301.

Muutos maa- ja metsätalousministeriön päätökseen nisäkäs- ja lintulajeihin kuuluvien tuotantoeläinten lopettamiselle asetettavista eläinsuojeluvaatimuksista. (MMMp 5/EEO/2000). Viitattu 22.11.2011. Luettavissa internetissä, http://wwwb.mmm.fi/el/laki/f/f11m1.html.

Neuvoston asetus (EY N:o 1099/2009) eläinten suojelusta lopetuksen yhteydessä. Viitattu 22.11.2011. Luettavissa internetissä, http://eur-lex.europa.eu/LexUriServ/LexUriServ.do?uri=OJ:L:2009:303:0001 :0030:FI:PDF

Mohan Raj, A.B. \& Gregory, N.G. 1990. Effect of rate of induction of carbon dioxide anaesthesia on the time of onset of unconsciousness and convulsions. Research in veterinary science, 49(3), 360-363.

Raj, A.B.M., Gregory, N.G. \& Wotton, S.B. 1990. Effect of carbon-dioxide stunning on somatosensory evoked-potentials in hens. Research in veterinary science, 49(3), 355-359.

Webster, A.B. \& Fletcher, D.L. 2001. Reactions of laying hens and broilers to different gases used for stunning poultry. Poultry Science, 80(9), 1371-1377. 